\title{
PENGARUH GAYA BELAJAR TERHADAP HASIL BELAJAR MATEMATIKA SISWA KELAS VII SMP NEGERI 1 UNAAHA
}

\author{
Siti Jumroidah ${ }^{1)}$, Kadir $^{2)}$, Suhar $^{3)}$ \\ ${ }^{1)}$ AlumniJurusan Pendidikan Matematika, ${ }^{2,3)}$ Dosen Jurusan Pendidikan Matematika \\ FKIP Universitas Halu Oleo: email: siti_jumroidah@yahoo.com; kadirraea@yahoo.co.id; \\ suhar fkipmat@yahoo.com
}

\begin{abstract}
Abstrak
Penelitian expos facto ini bertujuan untukmengetahui pengaruh gayabelajar terhadap hasil belajar matematika secara terpisah dan secara bersama-sama. Populasi dalam penelitian ini adalah seluruh siswa kelas VII SMP N 1 Unaahadan sampel penelitian sebanyak 128 siswa dengan menggunakan tekhnik purposive sampling. Hasil pengujian hipotesis menunjukkan bahwa: (1) gaya belajar visual memiliki pengaruh yang signifikan terhadap hasil belajar matematika siswa kelas VII SMP N 1Unaaha, besarnya pengaruh gaya belajar visual yaitu $12,3 \%$; (2) gaya belajar auditorial memiliki pengaruh yang signifikan terhadap hasil belajar matematika siswa kelas VIII SMP N 1Unaaha, besarnya pengaruh gaya belajar auditorial yaitu 36,1\%; (3) gaya belajar kinestetik memiliki pengaruh yang signifikan terhadap hasil belajar matematika siswa kelas VII SMP N 1 Unaaha, besarnya pengaruh gaya belajar kinestetikyaitu 28,1\%; (4) gaya belajar visual, auditorial, dan kinestetik secara bersama-sama memiliki pengaruh yang signifikan terhadap hasil belajar matematika siswa SMP N 1 Unaaha, besarnya pengaruh gaya belajar visual, auditorial, dan kinestetik secara bersama-sama yaitu sebesar $22,5 \%$, sedangkan 77,5\% dipengaruhi oleh faktor lain yang tidak diteliti dalam penelitian ini.
\end{abstract}

Kata Kunci: gayabelajar visual, gaya belajar auditorial, gaya belajar kinestetik

\section{THE INFLUENCE OF LEARNING STYLEON STUDENT'S MATHEMATICS LEARNING OUTCOMESCLASS VII OF SMP NEGERI 1 UNAAHA}

\begin{abstract}
This expos research was aimed to know the influence of learning style towards mathematic learning result separatedly and collectively. The population of the research was all of the grade VII students of SMP N 1 Unaaha and while sample research was 128 students by purposive sampling technique. The hypothesis test result showed that: (1) visual learning style had significant impact towards mathematic learning outcomes of grade VII SMP N 1 UNAAHA students, the visual learning style impact was $12,3 \%$; (2) auditorial learning style had significant effect towards mathematic learning outcomes of grade VII SMP N 1 Unaaha. The impact auditorial learning stlye was $36,1 \%$; (3) kinestetic learning style had significant impact towards mathematic learning outcomes of grade VII SMP N 1 UNAAHA students, the kinestetic learning style impact was 28,1\%; (4) visual, auditorial, and kinestetic learning style collectively had significant effect towards mathematic learning outcomesof grade VIII SMP N 1 Unaaha students, the impact of visual, auditorial, and kinestetic learning style collectively was $22,5 \%$, while $77,5 \%$ was influenced by another factor that was not studied by this research.
\end{abstract}

Keywords : learning style, visual learning style, auditorial learning style, kinestetic learning style 


\section{Pendahuluan}

Perkembangan yang terjadi dalam kehidupan bermasyarakat, berbangsa dan bernegara tidak terlepas dari perkembangan ilmu pengetahuan dan teknologi serta seni dan budaya.Sementara itu, kemajuan ilmu pengetahuan dan teknologi tidak terlepas dari peran pendidikan.Pendidikan merupakan bagian hakiki dari kehidupan masyarakat.Oleh karena itu, masalah pendidikan merupakan tanggung jawab bersama antara keluarga, masyarakat dan pemerintah.

\section{Pendidikan merupakan kebutuhan} mendasar yang harus dimiliki oleh manusia.Tanpapendidikan manusia tidak akan bisa meningkatkan taraf hidupnya. Dengan adanya pendidikan diharapkan manusia akan lebih mampu untuk mengembangkan dirinya.

Masalah pendidikan adalah masalah yang sangat penting bagi manusia, karena pendidikan tersebut menyangkut kelangsungan hidup manusia. Menyadari akan hal tersebut, pemerintah sangat serius menangani masalah pendidikan, sebab dengan sistem pendidikan yang baik diharapkan muncul generasi penerus bangsa yang berkualitas dan mampu menyesuaikan diri untuk hidup bermasyarakat, berbangsa dan bernegara.

Dalam kamus besar bahasa indonesia, secara etimologis belajar memiliki arti "berusaha memperoleh kepandaian atau ilmu". Menurut Fudyartanto Baharuddin dan Wahyuni (2015: 15), definisi ini memiliki pengertian bahwa belajar adalah sebuah kegiatan untuk mencapai kepandaian atau ilmu.Disini usaha untuk mencapai kepandaian atau ilmu merupakan usaha manusia untuk memenuhi kebutuhannya mendapatkan ilmu atau kepandaian yang belum dipunyai sebelumnya.Sehingga dengan belajar itu manusia menjadi tahu, memahami, mengerti, dapat melaksanakan dan memiliki tentang sesuatu.

Belajar merupakan aktivitas yang dilakukan seseorang untuk mendapatkan perubahan dalam dirinya melalui pelatihanpelatihan atau pengalaman-pengalaman.Dengan demikian belajar dapat membawa perubahan bagi si pelaku, baik perubahan pengetahuan, sikap, maupun keterampilan. Dengan perubahan-perubahan tersebut, tentunya si pelaku juga akan terbantu dalam memecahkan permasalahan hidup dan bisa menyesuaikan diri dengan lingkungannya.

Dimyati dan Mudjiono (2006: 3-4) menyebutkan bahwa hasil belajar merupakan hasil dari suatu interaksi tindak belajar dan tindak mengajar. Dari sisi guru, tindak mengajar diakhiri dengan proses evaluasi hasil belajar. Dari sisi siswa, hasil belajar merupakan berakhirnya pengajaran dari puncak proses belajar. Selanjutnya, sesuai dengan pendapat Sudjana (2008: 22) bahwa hasil belajar adalah kemampuan yang dimiliki siswa setelah ia menerima pengalaman belajarnya.

Pelaksanaannya di sekolah, para siswa diwajibkan untuk mengikuti seluruh mata pelajaran tidak terkecuali mata pelajaran matematika.Matematika merupakan salah satu mata pelajaran yang dapat ditemukan pada setiap jenjang pendidikan terutama dikalangan siswa Sekolah Menengah.Tidak dipungkiri bahwa mata pelajaran matematika membuat beberapa kalangan siswa menemukan kesulitan.Jika ditelaah dari beberapa pendapat ahli mengenai matematika dapat ditarik garis besarnya bahwa matematika adalah ilmu tentang logika yang mempelajari materi berupa perhitungan, pengkajian sehingga bersifat penalaran.

Menurut Hartati (2013: 227), hasil belajar matematika adalah hasil akhir yang dimiliki oleh siswa berupa kemampuankemampuan dalam menguasai, memahami konsep dalam pelajaran matematika sebagai ilmu tentang logika mengenai bentuk, susunan, besaran dan konsep-konsep yang saling berhubungan satu sama lainnya yang menggunakan istilah serta didefinisikan dengan cermat, jelas dan akurat untuk membantu manusia dalam memahami dan menguasai permasalahan sosial, ekonomi, dan alam setelah melalui proses belajar.

Hasil belajar masih menjadi suatu masalah yang bersifat terus menerus dalam sejarah. Hasil belajar matematika yang dicapai merupakan hasil interaksi antara berbagai faktor yang mempengaruhinya baik dari internal individu atau eksternal individu. Faktor internal terdiri atas unsur jasmaniah (fisiologis) dan rohaniyah (psikologis) pembelajar. Unsur jasmaniah yaitu kondisi umum sistem otot dan kondisi dari organ-organ khusus terutama panca indra. Otot dalam keadaan lelah bisa mengurangi kinerja belajar individu, karena 
kelelahan juga berpengaruh terhadap kemampuan kerja kognitif dan semangat belajar.Kemudian unsur rohaniah. Banyak unsur psikologis yang berpengaruh terhadap kualitas proses dan hasil belajar siswa, namun yang paling menonjol diantaranya yaitu tingkat kecerdasan/intelegensi, sikap, bakat, minat dan motivasi (Kurniawan, 2014: 22).

Gaya belajar adalah salah satu aspek yang perlu mendapat perhatian. Gaya belajar merupakan cara termudah yang dimiliki oleh individu dalam menyerap, mengatur dan mengolah informasi yang diterima. Gaya belajar yang sesuai adalah kunci keberhasilan seseorang dalam belajar. Oleh karena itu, dalam kegiatan belajar, siswa sangat perlu dibantu dan diarahkan untuk mengenali gaya belajar yang sesuai dengan dirinya sehingga tujuan pembelajaran dapat dicapai secara efektif. Ketika siswa mengenali gaya belajarnya maka ia akan mudah menentukan metode belajar seperti apa yang harus digunakan.

Prashign (2007) dalam Jeanete dan Neleke (2016: 57) menyatakan bahwa kunci menuju keberhasilan dalam belajar dan bekerja adalah mengetahui gaya belajar atau bekerja yang unik dari setiap orang, menerima kekuatan sekaligus kelemahan diri sendiri dan sebanyak mungkin menyesuaikan preferensi pribadi dalam setiap situasi pembelajaran, pengkajian maupun pekerjaan.

Siswa pada umumnya akan sulit memproses informasi dalam satu cara yang dirasa tidak nyaman bagi mereka. Siswa memiliki kebutuhan belajar sendiri, belajar dengan cara yang berbeda, serta memproses informasi dengan cara yang berbeda. Sebagian orang mungkin memiliki gaya belajar tertentu yang dominan digunakan dalam berbagai situasi, sehingga kurang menggunakan gaya yang berbeda untuk situasi yang berbeda.

Dari beberapa definisi gaya belajar di atas dapat disimpulkan bahwa gaya belajar adalah cara berbeda yang dipakai seorang siswa dengan siswa yang lain dalam proses belajar yang meliputi bagaimana menangkap,mengatur, serta mengolah informasi yang diterima sehingga pembelajaran menjadi efektif.

Gaya belajar seseorang menentukan bagaimana dia bisa menyerap sesuatu melalui inderanya diantara panca inderanya, indera mana yang lebih berkembang pada saat proses belajar tersebut berlangsung. Kaitannya dengan mata pelajaran matematika siswa di tuntut memiliki keterampilan menggunakan rumus dan keterampilan tertentu adalah salah satu yang berperan dalam menentukan kemampuan siswa dalam menyelesaikan dan manyerap materi pelajaran tersebut.

Menurut Asrori (2007: 22), berdasarkan kemampuan yang dimiliki otak dalam menyerap, mengelola dan menyampaikan informasi, maka cara belajar individu dapat dikelompokkan ke dalam tiga gaya belajar: (a) gaya belajar visual, (b) gaya belajar auditif, (c) gaya belajar kinestetik. Menurut Tracy (dalam terjemahan Lastiati, 2007: 289), orang-orang visual senang melihat segala sesuatunya terpampang jelas dihadapan mereka.Mereka memproses informasi dengan menggunakan mata mereka. Sedangkan seorang pembelajar auditory senang mendengarkan orang lain, mendengarkan program-program audio, bukubuku radio, musik, perkuliahan, pidato, dan seminar. Gaya belajar ketiga adalah kinestetis atau belajar dengan cara mengerjakan atau menyentuh sesuatu. Kaum kinestetis mengalami kesulitan jika mereka harus duduk dan tidak melakukan apa-apa. Adanya pengkategorian ini tidak berarti bahwa individu hanya yang memiliki salah satu karakteristik cara belajar tertentu saja sehingga tidak memiliki karakteristik cara belajar yang lain. Pengkategorian ini merupakan panduan bahwa individu memiliki kecenderungan kepada yang paling menonjol kepada salah satu diantara gaya belajar tersebut. Kecenderungan ini menyebabkan individu yang bersangkutan jika memperoleh rangsangan yang sesuai dalam belajar akan cenderung lebih untuk menyerapnya.

Guru harus dapat memenuhi kebutuhan siswa dalam belajar, sehingga belajar menjadi sesuatu yang menarik dan menyenangkan serta tidak membosankan. Kreativitas guru sangat dibutuhkan untuk mengolaborasikan berbagai metode atau multimetode, multistrategi, multimodel, multimedia dan aktivitas belajar sesuai dengan materi yang diajarkan sehingga memiliki kesempatan yang luas untuk beraktivitas dalam kegiatan pembelajaran. Pembelajaran yang dapat mengakses ketiga tipe gaya belajar tersebut adalah pembelajaran yang berorientasi aktivitas siswa dengan menggunakan berbagai macam pendekatan dan 
media pembelajaran. Jadi, pembelajaran boleh saja dilakukan secara klasikal tetapi sentuhannya harus individual, artinya guru harus menyentuh siswa yang auditif dengan ceramah dan penjelasan guru, bagi siswa yang visual, guru menggunakan berbagai alat dan media pembelajaran seperti media gambar, poster, LCD, CD interaktif, dan media visual lainnya, sedangkan yang tipenya kinestetik guru harus menyentuhnya dengan pengalaman langsung seperti praktik, eksperimen, peragaan, observasi dan unsur kinestetik lainnya (Rusman, 2017: 106).

Berdasarkan tipe-tipe di atas, gaya belajar menjadi salah satu peran penting siswa dalam menerapkan cara belajar yang cenderung ada pada dirinya sehingga hasil belajar yang dicapai dapat lebih optimal. Jika siswa belum mengetahui gaya belajar yang ada pada dirinya tidak menutup kemungkinan siswa yang bersangkutan tidak mampu menyerap materi ajar yang diberikan. Hal itu dapat mempengaruhi hasil belajar siswa.

\section{Metode}

Penelitian ini termasuk jenis penelitian expost facto dengan pendekatan kuantitatif.Penelitian expost facto merupakan penelitian yang dilakukan untuk mengungkap peristiwa yang sudah terjadi, dan kemudian menelusuri kembali untuk mengetahui faktorfaktor yang dapat menimbulkan kejadian tersebut (Sujarweni, 2014: 8).

Penelitian ini dilaksanakan di SMP Negeri 1 Unaaha yang terletak di kecamatan Unaaha kabupaten Konawe, mulai tanggal 26 Oktober sampai tanggal 03 November 2017 semester ganjil tahun ajaran 2017/2018.

Populasi dalam penelitian ini adalah seluruh siswa kelas VII SMP Negeri 1Unaaha tahun ajaran 2017/2018 yang tersebar dalam enam kelas dengan jumlah keseluruhan siswa sebanyak 209. Tehnik pengambilan sampel yaitu menggunakan tehnik purposive sampling yakni pengambilan sampel berdasarkan tujuan tertentu. Sampel diambil dengan pertimbangan yaitu satu kelas yang nilai rata-ratanya hasil belajar matematika tinggi, dua kelas memiliki rata-rata sedang, dan satu kelas memiliki ratarata rendah, sehingga jumlah sampel yang diperoleh sebanyak empat kelas yang berjumlah 128 siswa.Dalam penelitian ini, terdapat satu variabel bebas dan satu variabel terikat. Variabel bebasnya adalah gaya belajar $(\mathrm{X})$, sedangkan variabel terikat pada penelitian ini adalah hasil belajar matematika (Y).

Desain yang diterapkan adalah menghubungkan satu variabel bebas terhadap variabel terikat, sebagaimana ditunjukkan pada gambar 1 berikut:

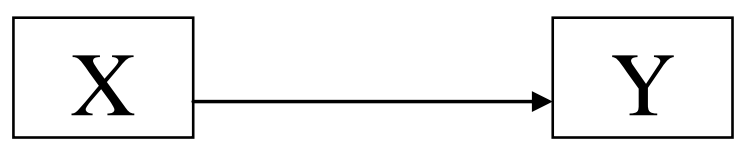

Gambar 1.Hubungan antara variabel bebas dan variabel terikat

Dalam penelitian ini digunakan analisis validitas, analisis reliabilitas, analisis statistik deskriptif, dan analisis statistik inferensial. Statistik deskriptif dimaksudkan untuk mendeskripsikan atau menggambarkan variabelvariabel penelitian (masing-masing gaya belajar) dalam bentuk rata-rata, median, modus, standar deviasi, dan varians data. Analisis statistik inferensial yaitu digunakan analisis regresi linear sederhana dan regresi berganda menggunakan IBM SPSS statistk 21.Analisis regresi ini dilakukan untuk menguji hipotesis penelitian.

Uji validitas adalah suatu ukuran yang menunjukkan keshahihan atau tingkat kevalidan suatu instrumen, dan ini mutlak dilakukan oleh peneliti untuk mencapai tujuan yang telah ditetapkan. Untuk mengetahui tingkat kesahihan atau kevalidan item, digunakan rumus Korelasi Product Moment Pearl Person yakni sebagai berikut: 


$$
\mathrm{r}_{\mathrm{xy}}=\frac{N \sum X Y-\left(\sum X\right)\left(\sum Y\right)}{\sqrt{\left\{N \sum X^{2}-\left(\sum X\right)^{2}\right\}\left\{N \sum Y^{2}-\left(\sum Y^{2}\right)\right\}}} \text { Arikunto (2002: 72) }
$$

di mana:

$$
\begin{aligned}
& r_{X Y}=\text { koefisien korelasi (Validitas item) } \\
& N=\text { jumlah responden } \\
& X=\text { skor responden pada setiap butir } \\
& Y=\text { skor total responden }
\end{aligned}
$$

Setelah dilakukan uji validitas angket, maka selanjutnya dilakukan uji reliabilitas. Uji reliabilitas digunakanuntuk menunjukkan

$$
r_{i i}=\frac{k}{(k-1)}\left\{1-\frac{\sum s_{i}^{2}}{s_{t}^{2}}\right\}
$$

di mana:

$\mathrm{k} \quad=$ banyaknya butir soal yang valid

$\sum \mathrm{s}_{\mathrm{i}^{2}} \quad=$ jumlah varian butir

$\mathrm{s}_{\mathrm{t}^{2}} \quad=$ varians total.

Interpretasi nilai $r_{i i}$ mengacu pada pendapat Guilford (Rusefendi, 1991: 191) dalam Jihad dan Haris (2013: 180-181):

$$
\begin{aligned}
& r_{11} \leq 0,20 \quad \text { reliabiltas : sangat } \\
& \text { rendah } \\
& 0,20<r_{11} \leq 0,40 \quad \text { reliabilitas : } \\
& \text { rendah } \\
& \begin{array}{ccc}
0,40<r_{11} \leq 0,70 & \text { reliabilitas } & : \\
\text { sedang } & & \\
0,70<r_{11} \leq 0,90 & \text { reliabilitas } & : \text { tinggi } \\
0,90<r_{11} \leq 1,00 & \text { reliabilitas } & : \text { sangat }
\end{array} \\
& 0,90<r_{11} \leq 1,00 \quad \text { reliabilitas } \quad \text { : sangat }
\end{aligned}
$$

Kaidah pengambilan keputusan untuk pengujian hipotesis dalam analisis regresi linear sederhana digunakan statistik uji tadalah sebagai berikut: (1) tolak $\mathrm{H}_{0}$, jika $t_{\text {hitung }} \geq \mathrm{t}_{\text {tabel }}$ pada $\alpha=$ 0,05 ; (2) terima $\mathrm{H}_{0}$, jika $\mathrm{t}_{\text {hitung }} \leq \mathrm{t}_{\text {tabel }}$ pada $\alpha=$ 0,05 . Sedangkan kaidah pengambilan keputusan tingkat konsistensi dan akurasi hasil pengukuran. Tingkat konsistensi tersebut diukur dengan menggunakan teknik Alpha Cronbach. untuk analisis regresi berganda adalah: (1) jika

$\mathrm{F}_{\text {hitung }} \geq \mathrm{F}_{\text {tabel }}$, maka tolak $\mathrm{H}_{0}$ artinya variabel masing-masing gaya belajar mempunyai pengaruh yang signifikan terhadap hasil belajar matematika; (2) jika $\mathrm{F}_{\text {hitung }}<\mathrm{F}_{\text {tabel}}$, maka terima $\mathrm{H}_{0}$ artinya variabel masing-masing gaya belajartidak mempunyai pengaruh yang signifikan terhadap hasil belajar matematika.

\section{Hasil}

\section{Analisis deskriptif}

Hasil analisis deskriptif data angket gaya belajar visual siswa distribusi skor yang diperoleh mulai dari 66 (skor minimum) sampai dengan 94 (skor maksimum). Rata-rata skor gaya belajar visual adalah 80,2 dengan modus sebesar 84, dan standar deviasi sebesar 7,29. Distribusi gaya belajar visual selengkapnya dapat dilihat pada tabel 1 .

\section{Tabel 1}

Distribusi Skor Gaya Belajar Visual Siswa

\begin{tabular}{|c|l|c|c|l|}
\hline No. & Interval & Frekuensi & Persentase & \multicolumn{1}{|c|}{ Kriteria } \\
\hline 1 & $\mathrm{X}>91,14$ & 6 & $10 \%$ & Sangat Tinggi \\
\hline 2 & $83,85<\mathrm{X} \leq 91,14$ & 16 & $26,678 \%$ & Tinggi \\
\hline 3 & $76,56<\mathrm{X} \leq 83,85$ & 22 & $36,67 \%$ & Sedang \\
\hline 4 & $69,27<\mathrm{X} \leq 76,56$ & 11 & $18,33 \%$ & Rendah \\
\hline 5 & $\mathrm{X}<69,27$ & 5 & $8,33 \%$ & Sangat Rendah \\
\hline & Jumlah & 60 & 100 & \\
\hline
\end{tabular}


Hasil analisis deskriptif data angket gaya belajar auditorial siswa distribusi skor yang diperoleh mulai dari 70 (skor minimum) sampai dengan 96 (skor maksimum). Rata-rata skor gaya belajar auditorial adalah 82,25 dengan modus sebesar 77, dan standar deviasi sebesar6,26. Distribusi gaya belajar auditorial selengkapnya dapat dilihat pada tabel 2.

Tabel 2

Distribusi Skor Gaya Belajar AuditorialSiswa

\begin{tabular}{|c|l|c|c|l|}
\hline No. & \multicolumn{1}{|c|}{ Interval } & Frekuensi & Persentase & \multicolumn{1}{|c|}{ Kriteria } \\
\hline 1 & $\mathrm{X}>91,64$ & 5 & $11,36 \%$ & Sangat Tinggi \\
\hline 2 & $85,38<\mathrm{X} \leq 91,64$ & 9 & $20,45 \%$ & Tinggi \\
\hline 3 & $79,12<\mathrm{X} \leq 85,38$ & 13 & $29,55 \%$ & Sedang \\
\hline 4 & $72,86<\mathrm{X} \leq 79,12$ & 15 & $34,09 \%$ & Rendah \\
\hline 5 & $\mathrm{X}<72,86$ & 2 & $4,55 \%$ & Sangat Rendah \\
\hline & Jumlah & 44 & 100 & \\
\hline
\end{tabular}

Hasil analisis deskriptif data angket gaya belajar kinestetik siswa distribusi skor yang diperoleh mulai dari 72 (skor minimum) sampai dengan 98 (skor maksimum). Rata-rata skor gaya belajar kinestetik adalah 85,58 dengan modus sebesar 91, dan standar deviasi sebesar6,16. Distribusi gaya belajar kinestetik selengkapnya dapat dilihat pada tabel 3 .

Tabel 3

Distribusi Skor Gaya Belajar kinestetik Siswa

\begin{tabular}{|c|l|c|c|l|}
\hline No. & \multicolumn{1}{|c|}{ Interval } & Frekuensi & Persentase & \multicolumn{1}{|c|}{ Kriteria } \\
\hline 1 & $\mathrm{X}>94,8$ & 1 & $4,17 \%$ & Sangat Tinggi \\
\hline 2 & $88,64<\mathrm{X} \leq 94,8$ & 7 & $29,17 \%$ & Tinggi \\
\hline 3 & $82,48<\mathrm{X} \leq 88,64$ & 10 & $41,67 \%$ & Sedang \\
\hline 4 & $76,32<\mathrm{X} \leq 82,48$ & 3 & $12,5 \%$ & Rendah \\
\hline 5 & $\mathrm{X}<76,32$ & 3 & $12,5 \%$ & Sangat Rendah \\
\hline & Jumlah & 24 & 100 & \\
\hline
\end{tabular}

sampai dengan 90,77 (nilai maksimum). Rata-

Hasil analisis deskriptif data variabel hasil belajar matematika siswa distribusi nilai hasil belajar matematika yang diperoleh siswa kelas VIISMP Negeri 1 Unaaha tahun ajaran 2017/2018 dimulai dari 27,69 (nilai minimum) rata nilai hasil belajar matematika siswa adalah 52,50 dengan standar deviasi 13,54. Distribusi nilai hasil belajar matematika siswa selengkapnya dapat dilihat pada tabel 4 .

Tabel 4

Distribusi Nilai Hasil Belajar Matematika Siswa

\begin{tabular}{|l|c|c|c|}
\hline Interval & Kritera & Frekuensi & Presentase (\%) \\
\hline$<X \leq 100$ & Sangat baik & 2 & 1,56 \\
\hline $73<X \leq 87$ & Baik & 5 & 3,91 \\
\hline $59<X \leq 73$ & Cukup & 36 & 28,13 \\
\hline$X<60$ & Kurang & 85 & 66,41 \\
\hline \multicolumn{2}{|c|}{ Jumlah } & 128 & 100 \\
\hline
\end{tabular}




\section{Uji persyaratan data}

Data yang telah dikumpulkan selanjutnya diuji persyaratan analisis yang meliputi uji normalitas.Uji normalitas data dimaksudkan untuk menguji kenormalan data dengan menggunakan Uji Kolmogorov-Smirnov dengan bantuan IBM SPSS 21 dan hasil uji normalitas diperoleh nilai Kolmogorov Smirnov Z untuk variabel gaya belajar sebesar 0,798 dengan Asymp. sig. (2-tailed) $=0,547>$ signifikan $(\alpha)=0,05$ artinya data sampel variabel gaya belajar berasal dari distribusi normal. Nilai Kolmogorov - Smirnov Z untuk variabel hasil belajar matematika siswa sebesar 0,775 dengan Asymp. sig. (2-tailed) = 0,585> signifikan $(\alpha)=0,05$ artinya data sampel variabel hasil belajar matematika siswa berasal dari distribusi normal.

\section{Pengujian hipotesis penelitian}

Uji regresi sederhana antara gaya belajar visual terhadap hasil belajar matematika memiliki sig $=0,006$ lebih kecil dari $\alpha=0,05$ yang dipilih atau dengan memperhatikan $\mathrm{t}_{\text {hitung }}=$ 2,853, selanjutnya dibandingkan dengan

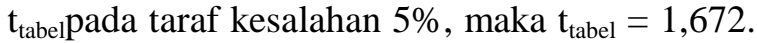
Ternyata $t_{\text {hitung }}=2,843>\mathrm{t}_{\text {tabel }}=1,672$. Hal ini berarti ditolaknya $\mathrm{H}_{0}$ dan terima $\mathrm{H}_{1}$. Artinya, ada pengaruh gaya belajar visual terhadap hasil belajar matematika siswa kelas VII SMP Negeri 1

Unaaha.

Persamaanregresiantaravariabelgayabel ajarvisualdengan hasil belajar matematikayaitu $\hat{Y}=0,701 X-4,680$. Hasil persamaan tersebut menunjukkan koefisen $X$ sebesar 0,701.Artinya, apabila gayabelajar visual meningkat 1 poin maka hasil belajar matematika siswa akan meningkat sebesar 0,701.Berdasarkan tabel 5, tampak bahwa hubungangaya belajar visual dengan hasil belajar matematika siswa, ditunjukkan oleh koefisien korelasi (R) sebesar 0,351 . Besarnya pengaruh gaya belajar visual terhadap hasil belajar matematika dapat dilihat pada koefisien determinasi ( $R$ Square) yaitu 0,123 artinya persentase sumbangan pengaruh gaya belajar visual hanya sebesar $12,3 \%$. Sedangkan sisanya sebesar $87,7 \%$ dipengaruhi oleh faktor lain yang tidak dibahas dalam penelitian ini.

Tabel 5

Hasil koefisien korelasi gaya belajar visual terhadap hasil belajar matematika (HBM)

\begin{tabular}{|l|r|r|r|c|}
\hline \multicolumn{7}{|c|}{ Model Summary } \\
\hline Model & $\mathrm{R}$ & R Square & Adjusted R Square & $\begin{array}{c}\text { Std. Error of the } \\
\text { Estimate }\end{array}$ \\
\hline 1 &, $351^{\mathrm{a}}$ &, 123 &, 108 & 13,74716 \\
\hline \multicolumn{5}{|c|}{ a. Predictors: (Constant), VISUAL } \\
\hline \multicolumn{5}{|c|}{ b. Dependent Variable: HBM } \\
\hline
\end{tabular}

Uji regresi sederhana antara gaya belajar auditorial terhadap hasil belajar matematika memiliki sig $=0,000$ lebih kecil dari $\alpha=0,05$ yang dipilih atau dengan memperhatikan $\mathrm{t}_{\text {hitung }}=$ 4,874, selanjutnya dibandingkan dengan $\mathrm{t}_{\text {tabelp }}$ pada taraf kesalahan 5\%, maka $\mathrm{t}_{\text {tabel }}=1,682$. Ternyata $\mathrm{t}_{\text {hitung }}=4,874>\mathrm{t}_{\text {tabel }}=1,682$. Hal ini berarti ditolaknya $\mathrm{H}_{0}$ dan terima $\mathrm{H}_{1}$. Artinya, ada pengaruh gaya belajar auditorial terhadap hasil belajar matematika siswa kelas VII SMP Negeri 1 Unaaha.Persamaan regresi antara variabel gaya belajar auditorial dengan hasil belajar matematika yaitu $\hat{Y}=1,215 X-46,607$. Persamaan tersebut menunjukkan koefisen $X$ sebesar 1,215.Artinya,apabila gayabelajar auditorial meningkat 1 poin maka hasil belajar matematika siswa akan meningkat sebesar 1,215.Berdasarkan tabel 6, tampak bahwa hubungangaya belajarauditorial dengan hasil belajar matematika siswa, ditunjukkan oleh koefisien korelasi (R) sebesar 0,601. Besarnya pengaruh gaya belajar visual terhadap hasil belajar matematika dapat dilihat pada koefisien determinasi ( $R$ Square) yaitu 0,361 artinya persentase sumbangan pengaruh gaya belajar visual hanya sebesar $36,1 \%$. Sedangkan sisanya sebesar $63,9 \%$ dipengaruhi oleh faktor lain yang tidak dibahas dalam penelitian ini. 
Tabel 6

Hasil koefisien korelasi gaya belajar auditorial terhadap hasil belajar matematika (HBM)

\begin{tabular}{|l|r|r|r|c|}
\hline \multicolumn{5}{|c|}{ Model Summary } \\
\hline Model & $\mathrm{R}$ & R Square & Adjusted R Square & $\begin{array}{c}\text { Std. Error of the } \\
\text { Estimate }\end{array}$ \\
\hline 1 &, $601^{\mathrm{a}}$ &, 361 &, 346 & 10,23416 \\
\hline \multicolumn{5}{|c|}{ a. Predictors: (Constant), AUDITORIAL } \\
\hline \multicolumn{6}{|c}{ b. Dependent Variable: HBM } \\
\hline
\end{tabular}

Uji regresi sederhana antara gaya belajar kinestetik terhadap hasil belajar matematika memiliki sig $=0,008$ lebih kecil dari $\alpha=0,05$ yang dipilih atau dengan memperhatikan $\mathrm{t}_{\text {hitung }}=$ 2,930, selanjutnya dibandingkan dengan

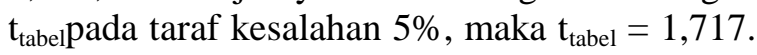
Ternyata $t_{\text {hitung }}=2,930>t_{\text {tabel }}=1,717$. Hal ini berarti ditolaknya $\mathrm{H}_{0}$ dan terima $\mathrm{H}_{1}$. Artinya, ada pengaruh gaya belajar kinestetik terhadap hasil belajar matematika siswa kelas VII SMP Negeri 1 Unaaha.Persamaan regresi antara variabel gaya belajar kinestetik dengan hasil belajar matematika yaitu $\hat{Y}=1,103 X_{3}-41,010$ persamaan tersebut menunjukkan

koefisen $X$ sebesar

1,103.Artinya, apabila gayabelajar kinestetik meningkat 1 poin maka hasil belajar matematika siswa akan meningkat sebesar

1,103.Untukmenyatakanbesarkecilnyasumbanga nvariabelgayabelajar

kinestetikterhadaphasilbelajar matematikadapat dilihat pada koefisien determinasi ( $R$ Square) yaitu 0,281 . Artinya, variabel gaya belajar kinestetik memberikan pengaruh terhadap hasil belajar matematika sebesar $28,1 \%$ dan sisanya sebesar $71,9 \%$ dipengaruhi oleh faktor lain yang tidak dikaji pada penelitian ini.

Tabel 7

Hasil koefisien korelasi gaya belajar kinestetik terhadap hasil belajar matematika (HBM)

\begin{tabular}{|c|c|c|c|c|}
\hline \multicolumn{5}{|c|}{ Model Summary } \\
\hline Model & $\mathrm{R}$ & R Square & Adjusted R Square & $\begin{array}{l}\text { Std. Error of the } \\
\text { Estimate }\end{array}$ \\
\hline 1 &, $530^{\mathrm{a}}$ & 281 & 248 & 11,11576 \\
\hline \multicolumn{5}{|c|}{ a. Predictors: (Constant), KINESTETIK } \\
\hline \multicolumn{5}{|c|}{ b. Dependent Variable: HBM } \\
\hline
\end{tabular}

Uji regresi berganda antara variabel gaya belajar visual, auditorial, dan kinestetiksecara bersama-sama terhadap hasil

belajar matematika dapat dilihat pada tabel 8 berikut.

Tabel 8

Hasil Uji F Variabel gaya belajar visual, auditorial, dan kinestetik Secara Bersama-sama terhadapHasil Belajar Matematika (HBM) Siswa Kelas VII SMPN 1Unaaha

\begin{tabular}{|l|l|r|r|r|c|c|}
\hline \multicolumn{7}{|c|}{ ANOVA $^{\text {a }}$} \\
\hline \multirow{3}{*}{1} & Sudel of Squares & \multicolumn{1}{c|}{ Df } & Mean Square & F & Sig. \\
\cline { 2 - 8 } & Regression & 5243,407 & 3 & 1747,802 & 12,019 &, $000^{\mathrm{b}}$ \\
\cline { 2 - 7 } & Residual & 18032,112 & 124 & 145,420 & & \\
\cline { 2 - 7 } & Total & 23275,519 & 127 & & & \\
\hline \multicolumn{7}{|c}{ a. Dependent Variable: HBM } \\
\hline
\end{tabular}


Berdasarkan Tabel 8, diperoleh bahwa nilai sig $=0,000$ lebih kecil dari $\alpha=0,05$ yang dipilih atau dengan memperhatikan $\mathrm{F}_{\text {hitung }}=$ 12,019 , selanjutnya dibandingkan dengan $F_{\text {tabel }}$ dengan taraf kesalahan $5 \%$, maka harga $\mathrm{F}_{\text {tabel }}$ yang diperoleh $=2,68$. Ternyata $F_{\text {hitung }}=12,019>$ $\mathrm{F}_{\text {tabel }}=2,68$. Hal ini menunjukkan diterimanya $\mathrm{H}_{1}$ dan tolak $\mathrm{H}_{0}$. Artinya, ada pengaruh yang signifikan gaya belajar visual, auditorial, dan kinestetik secara bersama-sama terhadap hasil belajar matematika siswa kelas VII SMP Negeri 1 Unaaha.

Berdasarkan hasil analisis regresi ganda, bahwa hubungan gaya belajar visual, auditorial, dan kinestetik secara bersama-sama terhadap hasil belajar matematika siswa dapat ditunjukkan oleh koefisien korelasi (R) sebesar 0,475 . Besarnya pengaruh gaya belajar visual, auditorial, dan kinestetik secara bersama-sama terhadap hasil belajar matematika siswa dapat dilihat pada koefisien determinasi ( $R$ Square) yaitu 0,225 atau $22,5 \%$ yang menunjukkan bahwa hasil belajar matematika siswa kelas VII SMP Negeri 1 Unaaha dipengaruhi oleh gaya belajar visual, auditorial, dan kinestetik secara bersama-sama sebesar 22,5\% sedangkan sisanya sebesar 77,5\% dipengaruhi oleh faktor lain yang tidak diteliti dalam penelitian ini.

\section{Pembahasan}

Pada umumnya siswa akan sulit memproses informasi dalam satu cara yang dirasa tidak disukai/nyaman bagi mereka. Siswa memiliki kebutuhan belajar sendiri, dimana mereka akan belajar sesuai dengan cara yang berbeda untuk situasi yang berbeda pula. Disinilah peran penting dari gaya belajar yang dimiliki tiap siswa, mereka dapat mengoptimalkan gaya belajar yang dimilikinya sehingga tujuan belajar menjadi tercapai. Gaya belajar menentukan bagaimana dia bisa menyerap sesuatu informasi melalui inderanya diantara panca inderanya, indera mana yang lebih berkembang pada saat proses belajar tersebut berlangsung. Hal ini juga tidak lepas dari pengetahuan guru akan cara belajar yang dimiliki siswanya agar mudah bagi guru untuk menyampaikan informasi secara lebih efektif dan efisien.

Mata pelajaran matematika terkenal sulit bagi sebagian siswa karena materi bersifat abstrak, selain itu siswa juga harus dapat mengaplikasikan dalam kehidupan sehari-hari dari konsep yang telah dipelajari.Hal inilah yang membuat hasil belajar matematika siswa menjadi rendah. Kurangnya latihan dan pentingnya membuat belajar sesuai dengan cara yang disukai serta mengatur jadwal belajar juga menjadi salah satu pemicu rendahnya hasil belajar matematika. Oleh karena itu setiap siswa perlu mengetahui gaya belajar yang dimilikinya agar dalam proses menyerap informasi menjadi mudah dan cenderung lebih banyak menyerap materi yang diajarkan oleh guru. Ketika siswa mengetahui gaya belajarnya maka ia akan menerapkan cara belajar yang sesuai dengan keinginannya dan metode belajar yang efektif untuk dirinya. Dengan menggunakan dominan gaya belajar yang dimiliki setiap siswa maka sesuai dengan teori, hasil belajar matematika yang diperoleh akan memuaskan. Hal ini juga tidak luput dari pengetahuan guru dalam mengenali gaya belajar siswanya karena guru sangat berperan penting terhadap proses belajar yang dilakukan. Guru dapat membagi metode mengajarnya yang sesuai dengan gaya belajar peserta didiknya. Hal ini untuk menghindari sebagian peserta didik yang tidak menerima materi pelajaran secara maksimal dikarenakan siswa tidak senang dengan cara mengajar guru.

Berdasarkan hasil pengujian hipotesis 1 diperoleh bahwa gaya belajar visual berpengaruh positif terhadap hasil belajar matematika siswa kelas VII SMP Negeri 1 Unaaha. Hal ini dapat diketahui pada $\mathrm{t}_{\text {hitung }}=$ $2,853>t_{\text {tabel }}=1,672$ dan nilai signifikan $=0.006$ $<\alpha=0,05$. Artinya, gaya belajar visual mempunyai konribusi positif yang signifikan terhadap hasil belajar matematika. Hal ini sesuai dengan penelitian yang dilakukan Aswar dan Nilam (2013) yang menyimpulkan bahwa terdapat pengaruh gaya belajar visual, auditori, dan kinestetik terhadap hasil belajar matematika siswa kelas VII SMP Negeri di kabupaten Soppeng.

Selanjutnya, dari hasil analisis regresi sederhana diperoleh persamaan regresi yaitu $\hat{Y}=0,701 X_{1}-4,680$. Persamaan tersebut menunjukkan koefisen $X_{I}$ sebesar 0,701.Hal ini berartiapabila variabel gayabelajar visual dinaikkan 1 satuan maka hasil belajar matematika siswa akan meningkat sebesar 0,701 . Terlihat juga bahwa nilai konstan dari persamaan tersebut negatif, hal ini dikarenakan pengaruh yang diberikan gaya belajar visual 
terhadap hasil belajar matematika tergolong lemah, dan rentang nilai yang diperoleh siswa antara gaya belajar visual dan hasil belajar matematika jauh.

Kemudian dari hasil analisis regresi sederhana juga ini didapatkan besarnya koefisien korelasi yakni 0,351.Maknadarihasilanalisisregresidan

besarnya koefisien korelasi tersebutyaitu menunjukkan

semakintinggigayabelajarvisualsiswa,makaakans emakin baikpulahasil belajar matematikanya.Berarti

terdapatpengaruhyangpositifdan

signifikangayabelajarvisualterhadaphasilbelajar matematika siswa kelas VII SMP Negeri 1 Unaaha.Olehkarenaitu

dapatdikatakanbahwasemakintinggigayabelajarv isualyangdimiliki

olehsiswaakanmemberikanpengaruhyangsignifik an terhadap peningkatanhasilbelajar matematikanya.

Berdasarkanteoriyangdiungkapkan

olehDePorterdan

Hernacki

bahwasiswayangbergayabelajarvisual,yangmeme gangperanan penting adalahmata/penglihatan (visual),merekacenderungbelajarmelaluiapa

yangmerekalihat.Mereka

belajarlebihcepatdenganmenggunakan tampilantampilanvisual,seperti

diagram,bukupelajaranbergambar,dan

video.Matapelajaran matematika juga mempelajari gambar-gambar yang terdapat dalam konsep matematik, seperti bangun datar dan bangun ruang.Dalam pembelajaran,gurulebihdominanuntukmelakuka naktivitasvisualdengan

mewajibkansiswauntukmenyimakbuku

manual/gambar ilustrasi yang

diberikan.Siswadiberiwaktumembacadulusebelu

$\mathrm{m}$

gurumulaimenjelaskanmaterisecaralisan.Materi dalampembelajaran matematikajugaselalu menampilkangambar-gambardandiagram yangdisertakan di dalammateri tersebut.

Besarnya kontribusi gaya belajar visual terhadap hasil belajar matematika siswa kelas VII SMP Negeri 1 Unaaha dapat dilihat dari koefisien determinasi ( $R$ Square) yaitu 0,123 . Artinya, variabel gaya belajar visual memberikan kontribusi terhadap hasil belajar matematika sebesar $12,3 \%$ dan sisanya $87,7 \%$ dipengaruhi oleh variabel lain yang tidak dibahas pada penelitian ini.

Berdasarkan hasil pengujian hipotesis 2 diperoleh bahwa gaya belajar auditorial berpengaruh positif terhadap hasil belajar matematika siswa kelas VII SMP Negeri 1 Unaaha. Hal ini dapat diketahui pada $\mathrm{t}_{\text {hitung }}=$ $4,874>\mathrm{t}_{\text {tabel }}=1,682$ dan nilai signifikan $=0.000$ $<\alpha=0,05$. Hal ini dapat disimpulkan bahwa ada pengaruh gaya belajar auditorial terhadap hasil belajar matematika siswa kelas VII SMP Negeri 1 Unaaha. Selanjutnya, dari hasil analisis regresi sederhana diperoleh persamaan regresi yaitu $\hat{Y}=1,215 X_{2}-46,607$. Persamaan tersebut menunjukkan koefisen $X_{2}$ sebesar 1,215. Hal ini berartiapabila variabel gayabelajar auditorial dinaikkan 1 satuan maka hasil belajar matematika siswa akan meningkat sebesar 1,215. Terlihat juga bahwa nilai konstan dari persamaan tersebut negatif, hal ini dikarenakan pengaruh yang diberikan gaya belajar auditorial terhadap hasil belajar matematika tergolong lemah, dan rentang nilai yang diperoleh siswa antara gaya belajar auditorial dan hasil belajar matematika jauh.

Kemudian, dari hasil analisis regresi sederhana juga ini didapatkan besarnya koefisien korelasi yakni 0,601.Maknadarihasilanalisisregresidan

besarnya koefisien korelasi tersebutyaitu menunjukkan

semakintinggigayabelajarauditorialsiswa,makaa kansemakin tinggihasil belajar matematikanya.Berarti

terdapatpengaruhyangpositifdan

signifikangayabelajarauditorialterhadaphasilbela jar matematika siswa kelas VII SMP Negeri 1 Unaaha.Olehkarenaitu,

dapatdikatakanbahwasemakinoptimalpenggunaa ngayabelajarauditorial yang dimilikisiswamakaakanmemberikanpengaruh positif yangsignifikan terhadap peningkatanhasilbelajar matematikanya. Hal ini sesuai dengan teori DePorter dan Hernacki bahwa siswa yang bertipe gaya belajar auditorial mengandalkan kesuksesan belajarnya melalui indera pendengaran.

Berdasarkan teori yang diungkapkan oleh DePorter dan Hernacki bahwa siswa yang mempunyai gaya belajar auditori dapat lebih cepat memproses informasi dengan menggunakan diskusi verbal dan mendengarkan apa yang guru sampaikan. Dalam pembelajaran matematika, salah satu metode mengajar yang 
digunakan oleh guru dalam memberikan penjelasan terkait materi matematika adalah dengan metode ceramah, baik pada saat dalam proses pembelajaran berlangsung maupun praktek langsung. Dalam pembelajaran siswa auditorial tidak bisa fokus belajar ketika temannya yang lain sedang ribut, serta lebih sulit mengolah informasi dalam bentuk visual seperti sulitnya memahami/menggambar bentuk ruang. Oleh karena itu siswa yang bergaya belajar auditorial ini perlu banyak membutuhkan penjelasan verbal terkait materi matematika yang memakai ilustrasi/gambar dan lebih banyak memerlukan diskusi ketimbang belajar dengan menulis.

Besarnya kontribusi gaya belajar auditorial terhadap hasil belajar matematika siswa kelas VII SMP Negeri 1 Unaaha dapat dilihat dari koefisien determinasi ( $R$ Square) yaitu 0,361 . Artinya, variabel gaya belajar auditorial memberikan kontribusi terhadap hasil belajar matematika sebesar $36,1 \%$ dan sisanya $63,9 \%$ dipengaruhi oleh variabel lain yang tidak dibahas pada penelitian ini.

Berdasarkan hasil pengujian hipotesis 3 diperoleh bahwa gaya belajar kinestetik berpengaruh positif terhadap hasil belajar matematika siswa kelas VII SMP Negeri 1 Unaaha. Hal ini dapat diketahui pada $t_{\text {hitung }}=$ $2,930>t_{\text {tabel }}=1,717$ dan nilai signifikan $=0.006$ $<\alpha=0,05$. Hal ini dapat disimpulkan bahwa ada pengaruh gaya belajar kinestetik terhadap hasil belajar matematika siswa kelas VII SMP Negeri 1 Unaaha. Selanjutnya, dari hasil analisis regresi sederhana diperoleh persamaan regresi yaitu $\hat{Y}=1,103 X_{3}-41,010$. Persamaan tersebut menunjukkan koefisen $X_{3}$ sebesar 1,103 . Hal ini berartiapabila variabel gaya belajar kinestetik dinaikkan 1 satuan maka hasil belajar matematika siswa akan meningkat sebesar 1,103. Terlihat juga bahwa nilai konstan dari persamaan tersebut negatif, hal ini dikarenakan pengaruh yang diberikan gaya belajar kinestetik terhadap hasil belajar matematika tergolong lemah, dan rentang nilai yang diperoleh siswa antara gaya belajar kinestetik dan hasil belajar matematika jauh.

Kemudian, dari hasil analisis regresi sederhana juga ini didapatkan besarnya koefisien korelasi yakni 0,530.Maknadarihasilanalisisregresidan besarnya koefisien korelasi tersebutyaitu menunjukkan semakintinggigayabelajarkinestetik siswa,makaakansemakin tinggihasil belajar matematikanya.Berarti terdapatpengaruhyangpositifdan signifikangayabelajarkinestetikterhadaphasilbela jar matematika siswa kelas VII SMP Negeri 1 Unaaha.Olehkarenaitu,

dapatdikatakanbahwasemakinoptimalpenggunaa ngayabelajarkinestetik yang dimilikisiswamakaakanmemberikanpengaruh positif yangsignifikan terhadap peningkatanhasilbelajar matematikanya. Hal ini sesuai dengan penelitian yang dilakukan oleh Arylien dkk (2014) menyimpulkan bahwa terdapat pengaruh gaya belajar kinestetik terhadap prestasi belajar siswa SMK Negeri 5 Kupang.

Berdasarkan teori yang diungkapkan oleh DePorter dan Hernacki bahwa siswa yang bertipe gaya belajar kinestetik belajar melalui bergerak aktif, menyentuh, dan melakukan. Siswa dengan gaya belajar kinestetik ini tidak tahan apabila harus duduk berlama-lama mendengarkan materi pelajaran. Dalam pembelajaran matematika ini siswa dituntut untuk selalu berlatih mengerjakan soal-soal terkait materi matematika yang dipelajari. Hal ini menjadi perhatian khusus untuk siswa bertipe gaya belajar kinestetik karena keinginan mereka untuk selalu beraktivitas disertai kegiatan fisik. Guru bisa membuat kelompok belajar yang kemudian diiringi dengan games atau membuat media pembelajaran terkait matematika yang dapat membuat siswa yang memiliki gaya belajar kinestetik menjadi aktif serta fokus terhadap proses pembelajaran.

Besarnya kontribusi gaya belajar kinestetik terhadap hasil belajar matematika siswa kelas VII SMP Negeri 1 Unaaha dapat dilihat dari koefisien determinasi ( $R$ Square) yaitu 0,281 . Artinya, variabel gaya belajar kinestetik memberikan kontribusi terhadap hasil belajar matematika sebesar $28,1 \%$ dan sisanya $71,9 \%$ dipengaruhi oleh variabel lain yang tidak dibahas pada penelitian ini.

Dari hasil penelitian ini kontribusi yang diberikan gaya belajar kinestetik terhadap hasil belajar matematika siswa kelas VII SMP Negeri 1 Unaaha terbilang kecil. Hal ini terjadi karena siswa belum mengenali tipe gaya belajar yang ada pada dirinya. Saat mempelajari konsep materi yang berkaitan dengan pelajaran matematika mereka cenderung tidak memahami 
belajar yang sifatnya teoritis. Jadi guru disarankan untuk menggunakan media pembelajaran agar siswa dengan tipe gaya belajar kinestetik dapat terlibat aktif saat proses belajar mengajar.

Berdasarkan hasil uji hipotesis 4 diperoleh hasil analisis regresi berganda dengan tiga prediktor untuk gaya belajar visual, auditorial, dan kinestetik terhadap hasil belajar matematika dengan nilai $\mathrm{F}_{\text {hitung }}=12,019>\mathrm{F}_{\text {tabel }}$ $=2,68 \mathrm{dan}$ nilai $\mathrm{sig}=0,000>\alpha$ yang ditetapkan yaitu 0,05 , sehingga pengujian secara statistik uji-F pun telah menunjukkan bahwa gaya belajar visual, auditorial, dan kinestetik secara bersamasama mempunyai pengaruh yang signifikan terhadap hasil belajar matematika. Hal ini sesuai dengan pendapat Marton dkk. (1984) dalam Ghufron (2014) bahwa kemampuan seseorang untuk mengetahui sendiri gaya belajarnya dan gaya belajar orang lain dalam lingkungannya akan meningkatkan efektivitasnya dalam belajar. Gaya belajar mampu mempunyai peran penting dalam bidang pendidikan.Marton juga menenmukan sekaligus mengukuhkan suatu kesimpulan tentang hubungan konsep belajar individu untuk belajar, dan hasil usaha individu untuk belajar. Keberadaan dari hubungan tersebut secara spesifik berupa gaya belajar dan pengukuran hasil belajar dan prestasi akademis.

Persamaan regresi ganda tiga prediktorantaravariabelgayabelajarvisual $\left(X_{1}\right)$,ga ya belajarauditorial

$\left(X_{2}\right)$ dangayabelajarkinestetik $\left(X_{3}\right)$ dengan hasilbelajarmatematika $(Y)$ yaitu

$\hat{Y}=1,001 X_{1}+1,372 X_{2}+0,394 X_{3}-24,359$.

Persamaantersebutmenunjukkan

koefisen $X_{1}$ sebesar 1,001.Koefisien $X_{2}$ sebesar 1,372. Hal ini berarti apabila gaya belajar auditorial $\left(X_{2}\right)$ meningkat 1 poin, maka hasil belajar matematika (Y) akan meningkat sebesar 1,372.Apabilagayabelajarvisual $\left(X_{1}\right)$ meningkat 1poin, makahasilbelajar matematika $(Y)$ akan meningkat sebesar 1,001. Untuk gaya belajar kinestetik terlihat bahwa nilai signifikan sebesar $0,206>\alpha$ artinya gaya belajar kinestetik tidak berpengaruh terhadap hasil belajar matematika. Diketahui bahwa nilai konstan dari persamaan tersebut bernilai negatif. Hal ini dikarenakan pengaruh yang diberikan gaya belajar visual, auditorial, dan kinestetik secara bersama-sama terhadap hasil belajar matematika sangat kecil.
Berdasarkan

teoriyang

diungkapkanolehDunn\&Dunnbahwagaya

belajar merupakankumpulankarakteristik pribadiyangmembuat suatu pembelajaran menjadiefektif, maka siswa yang mampu memanfaatkan

gayabelajarnyadenganoptimalakanmemberikanp engaruhyangpositif dan signifikanterhadap perolehannilaihasilbelajarnya.

Dari hasil analisis regresi linear berganda dengan tiga prediktor diketahui koefisien korelasi sebesar 0,475 . Nilai koefisien korelasi tersebut menunjukkan bahwa hubungan antara variabel ketiga gaya belajar dan hasil belajar matematika agak rendah menurut tabel interpretasi dari Arikunto. Namun, dapat ditarik kesimpulan bahwa semakin tinggi gaya belajar visual, auditorial, dan kinestetik secara bersamasama, maka hasil belajar matematika yang diperoleh akan tinggi pula. Besarnya kontribusi gaya belajar visual, auditorial, dan kinestetik secara bersama-sama terhadap hasil belajar matematika terlihat dari koefisien determinasi $(R$ Square) sebesar 0,225. Artinya, persentase sumbangan pengaruh gaya belajar visual, auditorial, dan kinestetik sebesar 22,5\%. Sedangkan sisanya sebesar $77,5 \%$ dipengaruhi oleh faktor lain yang tidak diteliti dalam penelitian ini.

Dataanalisispenelitianinimenunjukkanbahwavari abel gayabelajar visual,auditorial,dan kinestetik secarabersama-samamemberikan konstribusi terhadap kenaikan hasil belajar matematika yang relatif kecil, karena masih banyak siswa yang belum mengoptimalkan gaya belajar yang ada pada dirinya serta keseriusan dan sungguhsungguh dalam belajar juga perlu diperhatikan.

Untuk mengoptimalkan gaya belajar siswa maka diperlukan peran guru agar mengajak siswa mengenali dan memahami tipe gaya belajar yang sesuai dengan dirinya serta dapat memberdayakan gaya belajar tersebut semaksimal mungkin. Dengan mengetahui gaya belajar siswanya, guru diharapkan dapat merancang pembelajaran yang mengacu pengoptimalan gaya belajar siswa. Jika gaya mengajar guru sesuai dengan gaya belajar siswa, maka dalam memahami materi yang berkaitan dengan matematika akan mudah dipahami dan terkesan menyenangkan.

Gaya mengajar guru merupakan strategi pemindahan informasi yang diberikan kepada 
siswanya, sedangkan gaya belajar adalah bagaimana sebuah informasi dapat diterima dengan baik oleh siswanya. Oleh karena itu guru seharusnya memiliki data tentang gaya belajar siswanya. Penyesuaian gaya mengajar kepada siswa juga menjadi hal yang patut untuk diperhatikan.

\section{Simpulan dan Saran}

\section{Simpulan}

Berdasarkan hasil analisis dan pembahasan yang diperoleh maka dapat disimpulkan bahwa :

1. Gambaran gaya belajar siswa kelas VII SMP Negeri 1 Unaahadiperoleh:

a. siswa kelas VII SMP Negeri 1 Unaaha yang bertipe gaya belajar visual berjumlah 60 siswa berada pada interval $76,56<X \leq 83,85$ dengan rata-rata 80,2 dan standar deviasinya 7,29;

b. siswa kelas VII SMP Negeri 1 Unaaha yang bertipe gaya belajar auditorialberjumlah 44 siswa berada pada interval $72,86<\mathrm{X} \leq 79,12$ dengan rata-rata 82,25 dan standar deviasinya 6,26; dan

c. siswa kelas VII SMP Negeri 1 Unaaha yang bertipe gaya belajar kinestetikberjumlah 24 siswa berada pada interval $82,48<\mathrm{X} \leq 88,64$ dengan rata-rata 85,56 dan standar deviasinya 6,16 .

2. Hasil belajar matematika pada siswa kelas VII SMP Negeri 1 Unaaha termasuk dalam kategori kurang pada interval $0-59$ dengan rata-rata 52,50 dan standar deviasinya 13,54. Nilai Rata-rata hasil belajar matematika siswa bertipe gaya belajar visual 51,51 , nilai rata-rata pada siswa bergaya belajar auditorial adalah 53,36, sedangkan untuk siswa bertipe gaya belajar kinestetik diperoleh rata-rata hasil belajar matematikanya 53,40 .

3. Terdapat pengaruh yang positif dan signifikan gaya belajar visual terhadap hasil belajar matematika siswa kelas VII SMP Negeri 1 Unaaha, yang ditunjukkan dengan nilai signifikan $=0.006<\alpha=0,05$, dengan pengaruh sebesar $12,3 \%$ dan sisanya $87,7 \%$ dipengaruhi oleh variabel lain.

4. Terdapat pengaruh yang positif dan signifikan gaya belajar auditorial terhadap hasil belajar matematika siswa kelas VII SMP Negeri 1 Unaaha, yang ditunjukkan dengan nilai signifikan $=0.000<\alpha=0,05$, dengan pengaruh sebesar $36,1 \%$ dan sisanya $63,9 \%$ dipengaruhi oleh variabel lain.

5. Terdapat pengaruh yang positif dan signifikan gaya belajar kinestetik terhadap hasil belajar matematika siswa kelas VII SMP Negeri 1 Unaaha, yang ditunjukkan dengan nilai signifikan $=0.008<\alpha=0,05$, dengan pengaruh sebesar $28,1 \%$ dan sisanya $71,9 \%$ dipengaruhi oleh variabel lain.

6. Terdapat pengaruh yang positif dan signifikan gaya belajar visual, auditorial, dan kinestetik secara bersama-sama terhadap hasil belajar matematika siswa kelas VII SMP Negeri 1 Unaaha, yang ditunjukkan dengan nilai $\mathrm{F}_{\text {hitung }}=12,019>$ $\mathrm{F}_{\text {tabel }}=2,68$, dengan pengaruh sebesar $22,5 \%$ dan sisanya $77,5 \%$ dipengaruhi oleh variabel lain.

\section{Saran}

Berdasarkan pembahasan dan kesimpulan hasil penelitian, maka penulis memberikan saran-saran sebagai berikut.

1. Bagi guru, diharapkan dapat mengajak siswanya agar mengenali tipe gaya belajar yang ada pada masing-masing siswa dan menyadarkan siswanya akan pentingnya jika mengoptimalkan gaya belajar dengan baik. Guru juga harus menyesuaikan cara mengajarnya sesuai dengan tipe gaya belajar yang dimiliki siswa serta tidak monoton pada satu metode mengajar.

2. Bagi siswa, diharapkan dapat mengenali tipe gaya belajar yang ada pada dirinya, setelah mengetahui gaya belajar yang ada pada dirinya siswa diharapkan dapat mengoptimalkan kecenderungan gaya belajarnya sehingga tujuan pembelajaran dan hasil belajar yang dicapai dapat memuaskan.

\section{Daftar Pustaka}

Anas, Aswar Dan Nilam Permatasari Munir.(2013). Pengaruh Gaya Belajar Vak Terhadap Hasil Belajar Matematika Siswa.Jurnal Prosiding Seminar Nasional.Volume 2, Nomor 1: 233- 
240.ISSN : 2443-1109.

Arikunto, Suharsimi. (2002). Prosedur Penelitian. Jakarta: Rineka Cipta.

Arylien Ludji Bire, dkk. (2014). Pengaruh Gaya Belajar Visual, Auditorial, Dan kinestetik Terhadap Prestasi Belajar Siswa.Jurnal Kependidikan. Volume 44, Nomor 2: 168-174.

Asrori, Mohammad. (2007). Psikologi Pembelajaran. Bandung: CV Wacana Prima.

Baharuddin dan Nur Wahyuni.(2015). Teori Belajar Dan Pembelajaran. Yogyakarta: Ar-ruzz Media.

Brian, Tracy. (2007). Change Your Thinking, Change Your Life : Bebaskan Potensi Dahsyat Anda Untuk Kesuksesan Yang Tak Terbatas. Penerjemah Anies Lastiati. Bandung : Kaifa.

DePorter,Bobbi\&MikeHernacki.( 2002).Quantu mLearning:Membiasakan

BelajarNyamandanMenyenangkan.Band ung:Kaifa.

Dimyati dan Mudjiono.(2006). Belajar Dan Pembelajaran. Jakarta: PT. Rineka Cipta.

Ghufron, M. Nur dan Risnawita.(2014). Gaya Belajar Kajian Teoritik. Yogyakarta: Pustaka Pelajar.

Hartati, Leni. (2013). Pengaruh Gaya Belajar Dan Sikap Siswa Pada Pelajaran Matematika Terhadap Hasil Belajar Matematika.Jurnal Formatif.Volume 3, Nomor 3: 224-235. ISSN: 2088-351X.
Kurniawan, Deni. (2014). Pembelajaran

Terpadu Tematik. Bandung: Alfabeta.

Papilaya, Jeanete Ophilia dan Neleke Huliselan.(2016). Identifikasi Gaya Belajar Mahasiswa.Jurnal Psikologi Universitas Diponegoro. Volume 15, Nomor 1: 56-63.

Rusman.(2017). Belajar dan Pembelajaran Berorientasi Standar Proses Pendidikan. Kencana: Jakarta.

Sudjana, Nana. (2008). Penilaian Hasil Proses Belajar Mengajar. Bandung: PT Remaja Rosdakarya.

Sugiyono.(2015). Statistik Non Parametris Untuk Penelitian. Bandung: Alfabeta.

Sujarweni,V Wiratna. (2014). Metodologi Penelitian. Yogyakarta: Pustaka Baru Press.

Jihad, Asep dan Abdul Haris.(2013). Evaluasi Pembelajaran. Yogyakarta: Multi Perindo. 